\title{
A PATRON SAINT FOR BRITISH OPHTHALMOLOGISTS*
}

\author{
BY
}

\author{
JAMES A. ROSS \\ Bridge of Allan
}

FOSTER (1952), in his scholarly article on " The Legend and Shrine of Saint Triduana ", ends with these words:

If we accept the legend, it would appear, by analogy with that of Saint Lucia, that British ophthalmologists can claim a patron saint of their own.

The Legend.-Foster tells the story, as found in the breviary of Aberdeen, of how Saint Triduana, who was born in Colosse of an illustrious family, landed in Scotland about A.D. 337. The beauty of her eyes attracted a princely but unwelcome suitor. To escape his attentions, she retired to a secret place, plucked out her eyes, and sent them to him impaled on a wooden pin.

In the same breviary (Mackinlay, 1914) is to be found the legend of Saint Medana (variants Modwenna, Monenna, Medan, and Maiden). Also of an illustrious family, she was born in Ulster, and was remarkable for the beauty of her eyes. Pursued by a knight, she took refuge with her attendants on a rock off the Irish shore. Miraculously this became a boat and in it they crossed to Scotland, landing at the Rhinns of Galloway. Her suitor followed, but she took refuge in a tree, where in his presence she plucked out her eyes and cast them on the ground at his feet. A spring of water appeared and in that she washed the blood from her face. Thereafter it bore her name. The two legends are therefore essentially the same.

The Chapels, Shrine, and Wells of St. Medana.-Under her invocation many chapels were erected. Those on the three great strongholds, the rocks of Edinburgh, Stirling, and Dumbarton have long since disappeared, but in Galloway where three chapels were built the ruins of one still exists at Kirkmaiden-in-Rhinns. Here was her shrine and three of the four wells known to bear her name; they are very fully described by Trotter and Maxwell (1886), who repeat the legend given above, tell of the finding of numerous votive offerings at the shrine, and describe the annual pilgrimage in May for the healing of the sick at the three wells. The smallest of these is $18^{\prime \prime}$ wide and $18^{\prime \prime}$ deep, and with its water the eyes were bathed after the patient's head had been dipped into the largest well and the lower part of his body and his legs into the second. "Saxon" (1878) wrote:

The water of this well was carried to all parts of the country and sold for the cure of sore eyes.

*Received for publication February 22, 1954. 
These "wells" had no spring to supply them, being filled by the sea at full tide. A sketch by Stirling Maxwell accompanies Trotter's description; another is to be found in the official report of the Royal Commission on Ancient and Historical Monuments (1912). The date assigned by the archaeologists is the 5th century, so the chapel shares with monuments at Whithorn and the "Lost Stone of Kirkmadrine" the distinction of being one of the oldest Christian constructions in Scotland.

The history of one other chapel remains to be told. Between Scone Palace and the Mercat Cross of the vanished royal city of Scone, and facing the site of the once great abbey, rises a gentle eminence, the Collis Credulitatis. Here laws were proclaimed and Kings crowned from 844 until 1651. On this "Hill of Faith" was erected a chapel dedicated to Saint Monenna. This was later replaced by the parish church of Scone which was rededicated to her. In a pew in this church,* Charles II took the coronation oath as King of Scots in 1651, 9 years before he was crowned at Westminster on the Stone of Scone.

Thus Saint Medana, while sharing equally the legend with Saint Triduana (who was Scottish by adoption only), was born in Ireland and lived her life in Scotland. Her connection with England, if tenuous, is historic.

Her cult must have been a strong one as the sites of her chapels show. To her ancient shrine, still to be seen, came the sick, and in one of her wells their eyes were bathed. The water from this well was sold as a cure for sore eyes.

To Saint Medana therefore, British ophthalmologists may turn for their patron saint unless another more acceptable comes to light.

I am indebted to Miss Watson of the Sandeman Library, Perth, for her valuable assistance.

\section{REFERENCES}

BANKs, M. M. (1937). “ British Calendar Customs. Scotland”, vol. 1, p. 150. Folk Lore Society; Glaisher, London.

FOSTER, J. (1953). British Journal of Ophthalmology, 37, 763.

MACKINLAY, J. M. (1914). "Ancient Church Dedications in Scotalnd". Non-Scriptural Dedications, p. 131. Douglas, Edinburgh.

MACKINTOSH, J. (1892). "The History of Civilisation in Scotland", rev. ed. vol. 1, p. 120. Gardner, Paisley.

MCNeIL, C. (1952). Uniy. Edinb. J., 16, 174.

ROYal Commission on THE ANCIENT and Historical Monuments and Constructions of SCOTLAND (1912). "Fourth Report. Monuments and Constructions in Galloway", vol. 1, County of Wigtown, p. 49. H.M.S.O., London.

"SAXON" (1878). "Galloway Gossip", 2nd. ed., p. 320. Choppington, Bedlington.

ScotT, H. (1917-23). "Fasti Ecclesiae Scoticanae", 2, pp. 340, 359, 375; 4, p. 250 . Oliver and Boyd, Edinburgh.

Trotter, R., and MaXWell, H. E. (1886). Proc. Soc. Antiquar. Scot., 20, (n.s.8) pp. 76, 90. Neill, Edinburgh.

\footnotetext{
*The church, rebuilt in 1783 , was removed stone by stone to New Scone in 1803 when the royal city was destroyed
} It is still in use and contains the historic pew. 